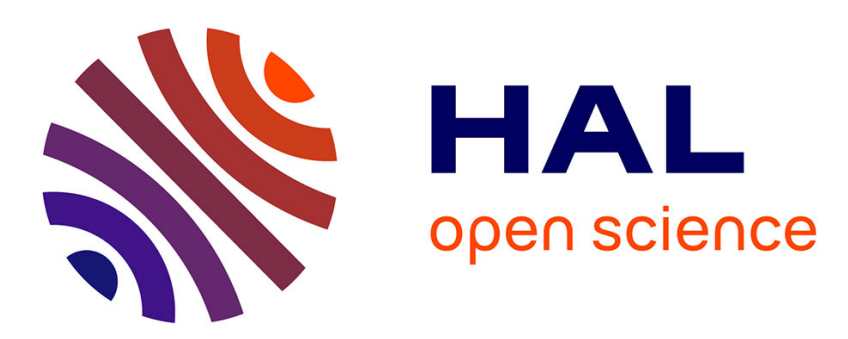

\title{
Translucent $\gamma$-AlOOH and $\gamma$-Al2O3 glass-ceramics using the cold sintering process
}

Thomas Hérisson de Beauvoir, Claude Estournès

\section{To cite this version:}

Thomas Hérisson de Beauvoir, Claude Estournès. Translucent $\gamma$-AlOOH and $\gamma$-Al2O3 glass-ceramics using the cold sintering process. Scripta Materialia, 2020, 194, pp.113650. 10.1016/j.scriptamat.2020.113650 . hal-03100689

\section{HAL Id: hal-03100689 \\ https://hal.science/hal-03100689}

Submitted on 6 Jan 2021

HAL is a multi-disciplinary open access archive for the deposit and dissemination of scientific research documents, whether they are published or not. The documents may come from teaching and research institutions in France or abroad, or from public or private research centers.
L'archive ouverte pluridisciplinaire HAL, est destinée au dépôt et à la diffusion de documents scientifiques de niveau recherche, publiés ou non, émanant des établissements d'enseignement et de recherche français ou étrangers, des laboratoires publics ou privés. 


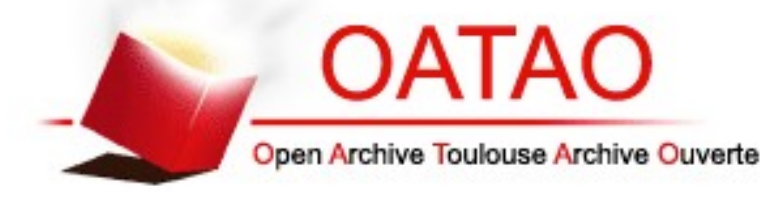

Open Archive Toulouse Archive Ouverte

OATAO is an open access repository that collects the work of Toulouse researchers and makes it freely available over the web where possible

This is an author's version published in: https://oatao.univ-toulouse.fr/27025

Official URL :

https://doi.org/10.1016/j.scriptamat.2020.113650

\section{To cite this version:}

Hérisson de Beauvoir, Thomas and Estournès, Claude Translucent $\gamma$-AlOOH and $\gamma$-Al2O3 glass-ceramics using the cold sintering process. (2020) Scripta Materialia, 194. 113650. ISSN 1359-6462

Any correspondence concerning this service should be sent to the repository administrator: tech-oatao@listes-diff.inp-toulouse.fr 


\title{
Translucent $\gamma$-AlOOH and $\gamma-\mathrm{Al}_{2} \mathrm{O}_{3}$ glass-ceramics using the cold sintering process
}

\author{
Thomas Hérisson de Beauvoir*, Claude Estournès \\ CIRIMAT, CNRS-INP-UPS, Université Toulouse 3 - Paul Sabatier 118 route de Narbonne, F-31062 Toulouse cedex 9, France
}

\section{A R T I C L E I N F O}

Keywords:

Sintering

Ceramics

Alumina

\begin{abstract}
A B S T R A C T
Cold Sintering Process has been applied to hydroxide precursors $\mathrm{Al}(\mathrm{OH})_{3}, \mathrm{xH}_{2} \mathrm{O}$ to promote in situ reactive sintering. The application of sintering temperatures $<400^{\circ} \mathrm{C}$ led to the release of $\mathrm{OH}$ groups and partial crystallization into boehmite $\gamma$-AlOOH. This latter step is accompanied by a densification stage leading to the production of dense translucent pellet. From skeletal density measurements, it appears that not all the pellet is composed of crystalline phase, but contains a mix of amorphous and crystalline phase. The presence of amorphous phase seems to favor the mechanical stability of the samples made of the intermediate boehmite phase, which is brittle due to its oriented layer structure. Further heat treatment in an oven at $500^{\circ} \mathrm{C}$ induces the transformation of boehmite into $\gamma-\mathrm{Al}_{2} \mathrm{O}_{3}$. Here we demonstrate the possibility to produce optically translucent ceramics of low temperature stability gamma alumina structure.
\end{abstract}

The recent development of cold sintering techniques has shown a great efficiency in the preparation of dense samples at extremely low temperatures [1-3]. The process is generally assumed to proceed through a pressure solution creep mechanism achieved under uniaxial high pressure (typically $>100 \mathrm{MPa}$ to GPa range) and mild temperatures $\left(<500^{\circ} \mathrm{C}\right)$. Although it appears that sintering mechanisms induce a dissolution step followed by a precipitation step, their precise description is not provided yet [4]. This way, dense bulk materials were obtained in various chemical media. A major challenge concerns materials with very low solubility in the experimental conditions (typically $<400^{\circ} \mathrm{C}$ under uniaxial pressure 100-800 MPa [5,6]). To densify such materials, alternative strategies have been developed, showing successful results. Ionic liquid was used to densify $\mathrm{BaTiO}_{3}$ in the absence of water, with densities reaching $98 \%$ of theoretical density at temperatures as low as $300^{\circ} \mathrm{C}$ without further heat treatment [7]. Another solution consists in activating sintering through a decomposition-reactive sintering. Following this route lead to the preparation of pure zirconia from hydroxide precursors $\mathrm{Zr}(\mathrm{OH})_{4}$ in just a few minutes at $350^{\circ} \mathrm{C}$ [8]. Recent work on $\mathrm{BaTiO}_{3}$ from $\mathrm{Ba}(\mathrm{OH})_{2}, 8 \mathrm{H}_{2} \mathrm{O}$ precursors also showed high densification rate (95\% relative density) without formation of $\mathrm{BaCO}_{3}$ [9]. This route offers a great potential for the preparation of metal oxides from low temperature decomposing hydroxides. Moreover, this also offers opportunities for

\footnotetext{
* Corresponding author. voir).

E-mail address: herisson-de-beauvoir@chimie.ups-tlse.fr (T. Hérisson de Beau-
}

the preparation of dense materials with very low decomposition temperatures [10] such as sulfates [11], carbonates [5,12], phosphates [13,14] but also oxides [6]. Alumina represents one of the most used oxide material, especially under the most stable phase $\alpha-\mathrm{Al}_{2} \mathrm{O}_{3}$. It also presents a large subset of metastable crystalline phases $(\gamma, \delta, \theta, \kappa, \varepsilon, \eta, \chi)[15]$. Among alumina crystalline phases, $\gamma-\mathrm{Al}_{2} \mathrm{O}_{3}$ is of particular interest for catalyst support application. Its lack of stability makes it difficult to densify into monolithic ceramics. However, densification could be performed under extremely high pressure, at $3 \mathrm{GPa}-500^{\circ} \mathrm{C}$ using a specific design [16]. Another possibility for $\gamma-\mathrm{Al}_{2} \mathrm{O}_{3}$ is to use it to promote densification of $\alpha-\mathrm{Al}_{2} \mathrm{O}_{3}$ phase through a phase transformation enhanced sintering $[17,18]$.

Here we propose to use the Cold Sintering Process starting from hydrated $\mathrm{Al}$ hydroxide to obtain dense samples of $\mathrm{AlOOH}$ with boehmite structure, which can further be heat treated to obtain samples of pure $\gamma-\mathrm{Al}_{2} \mathrm{O}_{3}$ phase.

Cold Sintering was performed on commercial $\mathrm{Al}(\mathrm{OH})_{3}, \mathrm{xH}_{2} \mathrm{O}$ (Sigma Aldrich) powder in a WC die at various temperatures ranging from $150^{\circ} \mathrm{C}$ to $400^{\circ} \mathrm{C}$ under $500 \mathrm{MPa}$ uniaxial pressure, for dwell times between 30 and $180 \mathrm{~min}$. After the dwell time, temperature was naturally decreased to room temperature and pressure was slowly released over $45 \mathrm{~min}$ to avoid pellet cracks. Some sintered samples were heat treated at $500^{\circ} \mathrm{C}$ for $2 \mathrm{~h}$ under air in a conventional furnace.

XRD patterns were recorded on the as received $\mathrm{Al}(\mathrm{OH})_{3}, \mathrm{xH}_{2} \mathrm{O}$ powder and treated at $500^{\circ} \mathrm{C}$ for $2 \mathrm{~h}$ as well as on a dense sample sintered at $380^{\circ} \mathrm{C}$ and subsequently annealed at $500^{\circ} \mathrm{C}$ in air. 

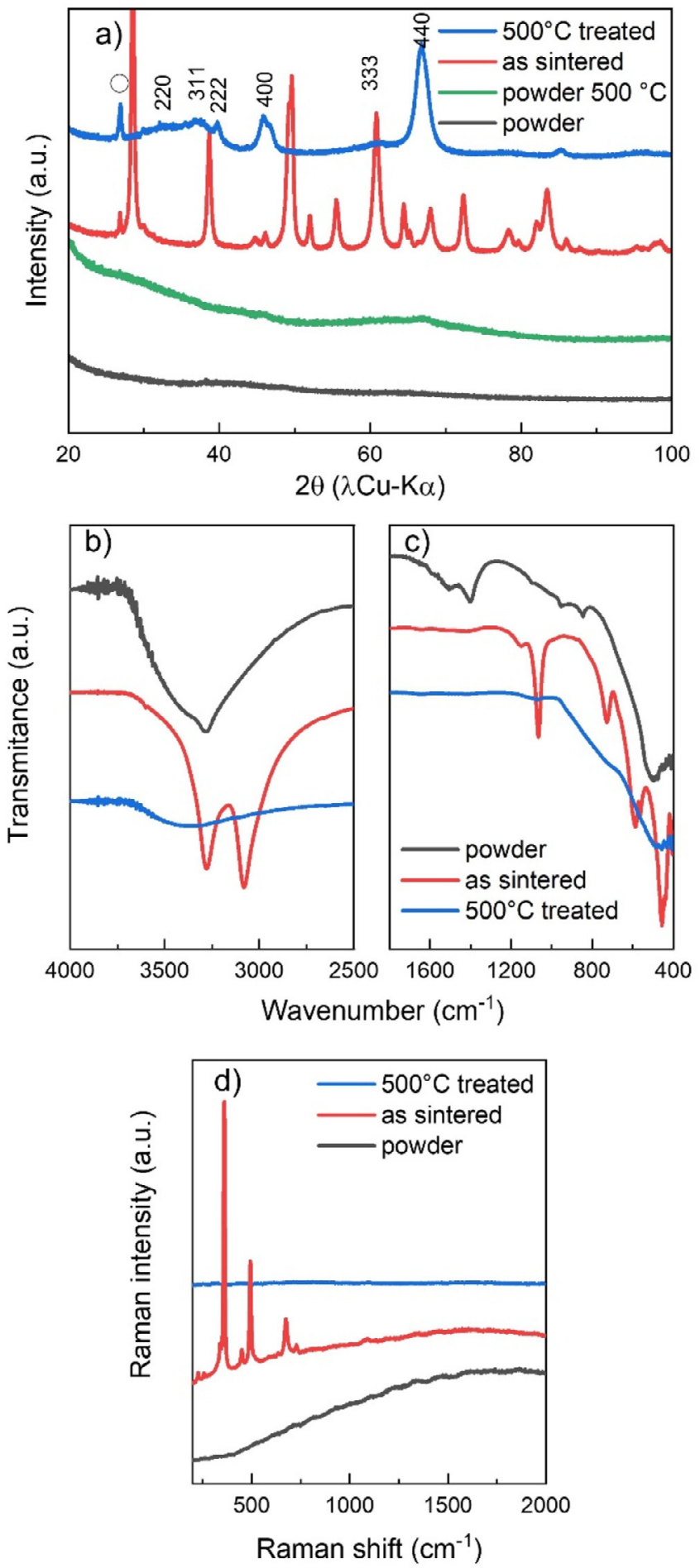

Fig. 1. a) XRD patterns of starting $\mathrm{Al}(\mathrm{OH})_{3}, \mathrm{H}_{2} \mathrm{O}$ powder, $380^{\circ} \mathrm{C}$ sintered pellet and $500^{\circ} \mathrm{C}$ treated pellet, b-c) corresponding FTIR spectra in ATR mode and d) corresponding Raman spectra ( $\mathrm{O}$ symbol in XRD represents graphite signature and $\gamma-\mathrm{Al}_{2} \mathrm{O}_{3}$ Miller indices are indicated above the corresponding peaks [25]). See Fig. 3 for boehmite peak positions.

As displayed on Fig. 1a, both the as received and $500^{\circ} \mathrm{C}$ treated powders display no crystallized phase. However, in the case of sintered sample, although the sintering temperature is only $380^{\circ} \mathrm{C}$, crystallization occurred inducing the formation of pure boehmite $\gamma$-AlOOH phase. After a $500^{\circ} \mathrm{C}$ treatment in an oven, the sintered pellet's structure changes to $\gamma-\mathrm{Al}_{2} \mathrm{O}_{3}$ phase, with no trace of remaining boehmite phase. To confirm this transition, FTIR and Ra- man spectroscopic measurements were performed. FTIR results are displayed on Fig. 1b-c. As received powder spectrum presents a broad peak around $500 \mathrm{~cm}^{-1}$, associated with two peaks at 1400 and $1510 \mathrm{~cm}^{-1}$, which are typical signature of $\mathrm{Al}(\mathrm{OH})_{3}[19,20]$. A broad peak from 2700 to $3700 \mathrm{~cm}^{-1}$ confirms the presence of water molecules in the powder, with a sharper peak at $3280 \mathrm{~cm}^{-1}$ denoting the presence of linked $\mathrm{OH}$ groups in the structure. FTIR pattern of sintered sample shows a sharp doublet at 3280 and $3080 \mathrm{~cm}^{-1}$, resulting from boehmite stretching mode of $\mathrm{AlO}-\mathrm{H}$, associated with a doublet at 1080 at $1160 \mathrm{~cm}^{-1}$ for Al-OH bending mode [21,22]. The three sharp peaks observed at 730, 600 and $480 \mathrm{~cm}^{-1}$ can be attributed to $\mathrm{Al}-\mathrm{O}_{6}$ stretching modes [22]. For the $500^{\circ} \mathrm{C}$ heated pellet, only a broad contribution from 3000 to $3700 \mathrm{~cm}^{-1}$ and a large peak at $500 \mathrm{~cm}^{-1}$ are observed, confirming the total absence of $\mathrm{AlOOH}$, therefore confirming the complete transition to $\gamma-\mathrm{Al}_{2} \mathrm{O}_{3}$ as observed in XRD. Fig. 1d displays Raman spectra of the same samples. While $\mathrm{AlOOH}$ has active modes in Raman, both $\mathrm{Al}(\mathrm{OH})_{3}$ and $\gamma-\mathrm{Al}_{2} \mathrm{O}_{3}$ have no active modes [23]. This makes the technique a great tool to evaluate the total transition from $\mathrm{AlOOH}$ to $\mathrm{Al}_{2} \mathrm{O}_{3}$. As displayed here, only the sintered sample displays bands at 360,450 and $495 \mathrm{~cm}^{-1}$, assigned to Al-O vibrational modes, as well as 730 and $674 \mathrm{~cm}^{-1}$ which can be assigned to $\gamma(\mathrm{OH})$ vibrational modes [24]. These bands confirm the boehmite structure of $\mathrm{AlOOH}$ phase. After heat treatment of this sample at $500^{\circ} \mathrm{C}$, no more active band is detected on the Raman spectrum, confirming the total phase transformation into $\gamma-\mathrm{Al}_{2} \mathrm{O}_{3}$.

According to these results, it is clearly evidenced that cold sintering process at temperatures below $400^{\circ} \mathrm{C}$ induces transition from amorphous $\mathrm{Al}(\mathrm{OH})_{3}$ to crystallized $\gamma$-AlOOH while as shown by the XRD the starting powder remains amorphous even after annealing at $500^{\circ} \mathrm{C}$.

For these three samples (powder, as sintered pellet and $500^{\circ} \mathrm{C}$ treated pellet) thermal analysis were performed from room temperature to $700^{\circ} \mathrm{C}$ and are presented in Fig. 2. Starting powder shows a massive loss of 38 wt.\% from 30 to $350^{\circ} \mathrm{C}$ which is associated to the removal of $\mathrm{H}_{2} \mathrm{O}$ molecules. This allows to determine the composition of the powder as $\mathrm{Al}(\mathrm{OH})_{3}, 0.5 \mathrm{H}_{2} \mathrm{O}$. DTA measurement shows an endothermic peak usually associated to the dehydration [26]. No further thermal event is observed at higher temperature up to $700^{\circ} \mathrm{C}$. The "as sintered" (Fig. 2b) pellet shows a first mass loss of $4.7 \mathrm{wt} . \%$ from room temperature to $200^{\circ} \mathrm{C}$ followed by a second loss of $16 \mathrm{wt} . \%$ up to $600^{\circ} \mathrm{C}$. The first loss is attributed to adsorbed water on the pellet, either resulting from the incomplete water removal along sintering experiment, or even from rehydration at room temperature after sintering in the remaining porosities. The second loss, associated with an endothermic peak in DTA, is assigned to the crystallization of boehmite into $\gamma-\mathrm{Al}_{2} \mathrm{O}_{3}$ (as observed in XRD at Fig. 1). This is consistent with the expected 17 wt.\% loss from the reaction $2 \mathrm{AlOOH} \rightarrow \mathrm{Al}_{2} \mathrm{O}_{3}+\mathrm{H}_{2} \mathrm{O}$ in the form of $\mathrm{H}_{2} \mathrm{O}$ molecules. For the sample heat treated $2 \mathrm{~h}$ at $500^{\circ} \mathrm{C}$ (Fig. 2C), a first loss is observed from room temperature to $200^{\circ} \mathrm{C}$ associated with the presence of water, which must be adsorbed from the atmosphere, as confirmed by the presence of a broad peak in FTIR (see Fig. 1b). However, up to $800^{\circ} \mathrm{C}$ no more loss is observed, and differential thermal analysis confirms the absence of the $\mathrm{AlOOH} \rightarrow \mathrm{Al}_{2} \mathrm{O}_{3}$ phase transition, as expected from XRD, Raman and FTIR analyses.

Fig. 3a presents the evolution of skeletal density of samples sintered at various temperatures, and measured in a He pycnometer on crushed pellets. Initially, the as received powder has a skeletal density of 2.16 g. $\mathrm{cm}^{-3}$ (represented by the point at $20^{\circ} \mathrm{C}$ ) which slightly increases after a $150^{\circ} \mathrm{C}$ sintering, reaching $2.21 \mathrm{~g} . \mathrm{cm}^{-3}$. A more drastic increase of the density occurs from $350^{\circ} \mathrm{C}$ to $400^{\circ} \mathrm{C}$ with a density of 3.05 g.cm ${ }^{-3}$ at $400^{\circ} \mathrm{C}$, which is the theoretical density of pure $\gamma$-AlOOH [27]. 

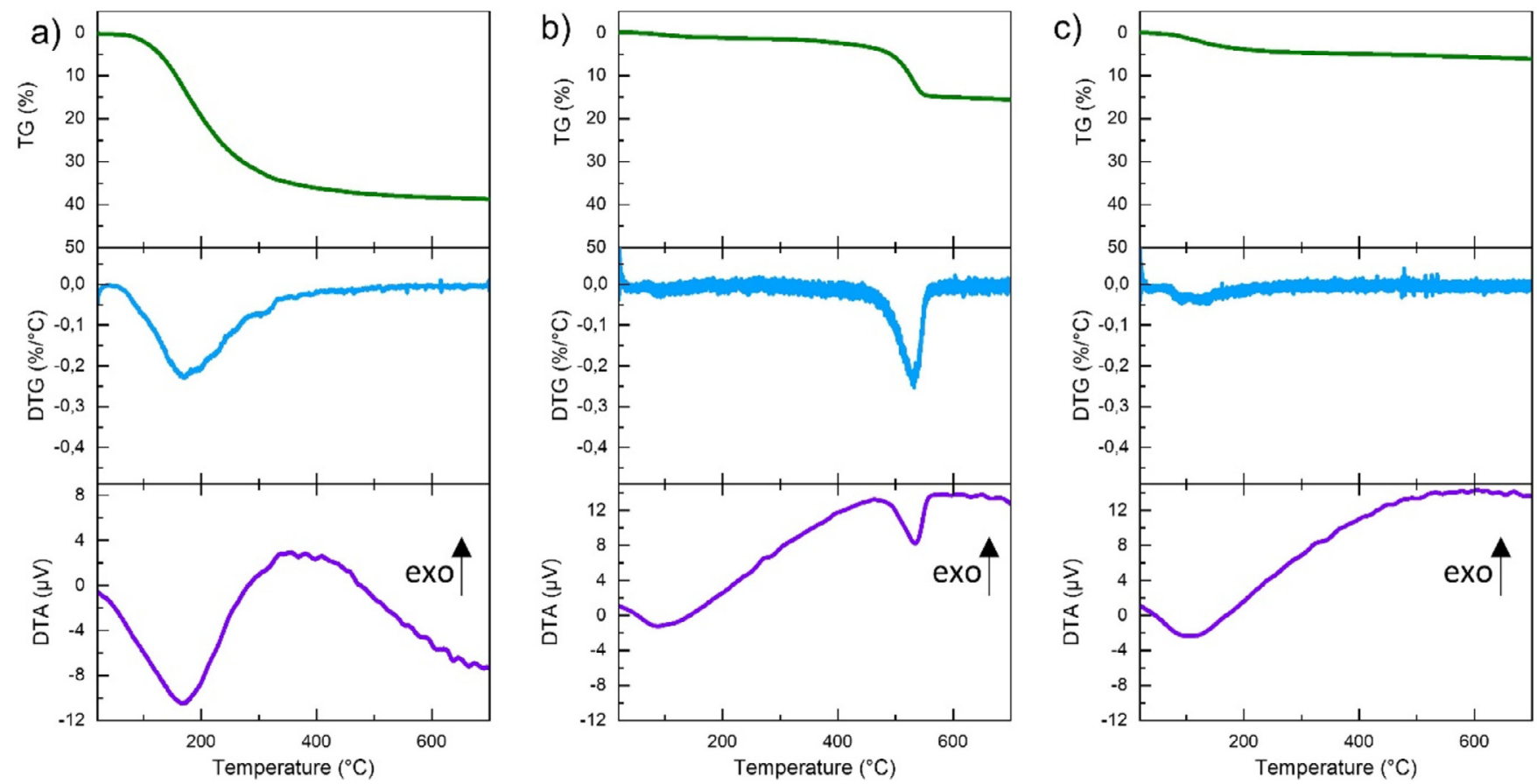

Fig. 2. Thermogravimetric and differential thermal analyses of a) powder, b) sintered pellet and c) $500^{\circ} \mathrm{C}$ treated pellet.
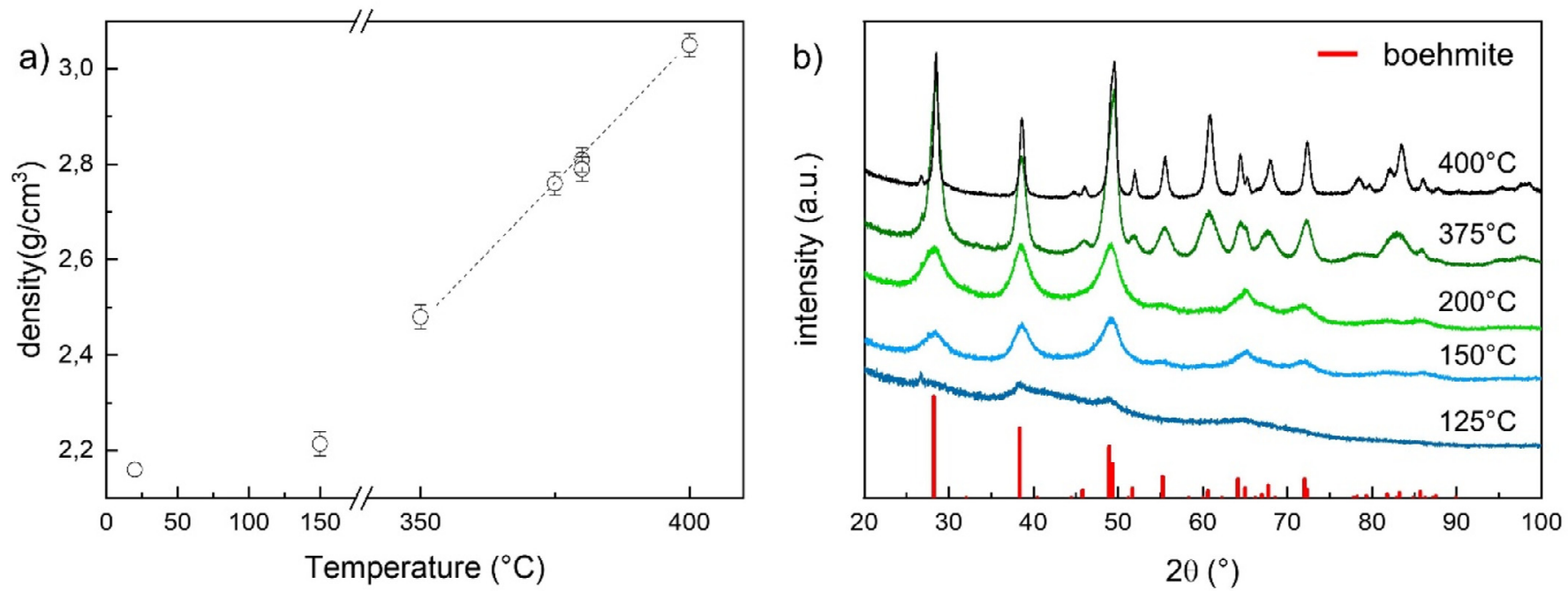

Fig. 3. a) Density measurements obtained from He pycnometer on crushed sintered pellets and b) XRD patterns of samples sintered at various temperatures.

XRD patterns of samples sintered at various temperatures are displayed on Fig. $3 \mathrm{~b}$. At $125^{\circ} \mathrm{C}$, small broad peaks are evidenced which are the first signature of the genesis of a crystallization phenomenon. Above this temperature, from $150^{\circ} \mathrm{C}$ to $400^{\circ} \mathrm{C}$, the peak intensity increases progressively up to $400^{\circ} \mathrm{C}$ with sharper peaks, indicating that crystallization has continued and/or that crystal size increases with sintering temperature. As a confirmation, crystallite sizes, obtained from Scherrer equation applied to XRD FWHM data indicate an average size evolution from $3 \mathrm{~nm}$ to $18 \mathrm{~nm}$ for sintering temperatures of 150 and $400^{\circ} \mathrm{C}$ respectively. He pycnometry measurements, along with XRD patterns, indicate that the formation of boehmite progressively occurs from 150 to $400^{\circ} \mathrm{C}$ from the amorphous $\mathrm{Al}(\mathrm{OH})_{3}, 0.5 \mathrm{H}_{2} \mathrm{O}$ powder, both visible in the XRD peak width and skeletal density increase. Since the only phase forming during sintering is $\mathrm{AlOOH}$ (having a theoretical density of $3.05 \mathrm{~g} . \mathrm{cm}^{-3}$ ) and skeletal density for samples sintered in the range $150^{\circ} \mathrm{C}<\mathrm{T}<380^{\circ} \mathrm{C}$ is progressively increasing, still below that of $\mathrm{AlOOH}$, it means they are composed of mixed amorphous $\mathrm{Al}(\mathrm{OH})_{3}$ and crystallized $\mathrm{AlOOH}$. This progressive evolution from amorphous to crystallized phase occurring up to $400^{\circ} \mathrm{C}$ allows producing samples with mixed composition of controlled crystallinity. This is an important asset of the present work since the preparation of mechanically coherent boehmite pellet is made difficult due to the layered structural nature [27], making it brittle. Thus, the resulting pellets after sintering most often break, by delamination, due to pressure release. This is why a careful slow pressure release is necessary to preserve the mechanical cohesion of the sample. In the case of samples sintered at temperatures lower than $400^{\circ} \mathrm{C}$ leading to a partial crystallization of the sample permits the preparation of cohesive samples. It appears that the presence of an amorphous phase allows for a stress absorption in the sample, and therefore allows to prepare cohesive samples.

Furthermore, we know from XRD patterns in Fig. 1 and TGA/DTA measurement in Fig. 2 that a $500^{\circ} \mathrm{C}$ treatment during 

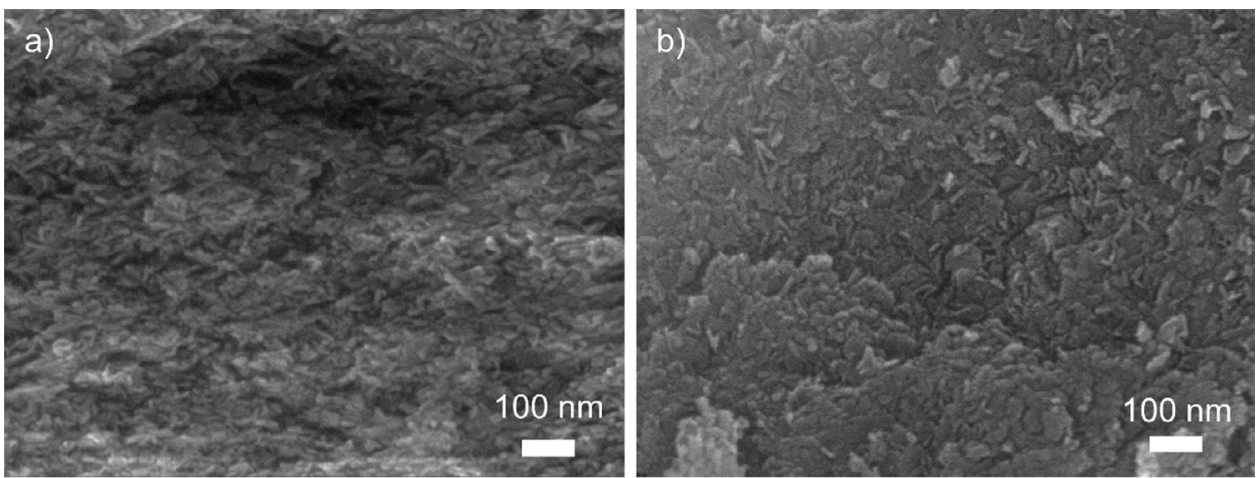

c)

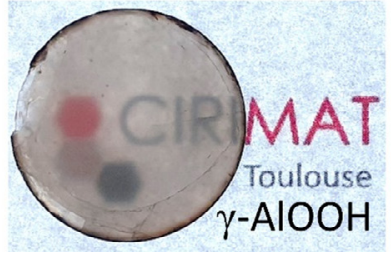

d)

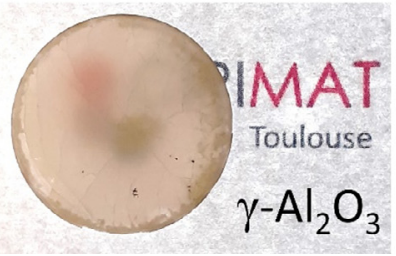

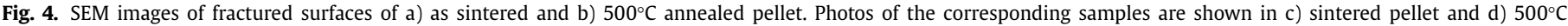
treated.

$2 \mathrm{~h}$ allows the complete phase transformation of $\gamma$-AlOOH to $\gamma$ $\mathrm{Al}_{2} \mathrm{O}_{3}$, but does not allow the crystallization of $\mathrm{Al}(\mathrm{OH})_{3}$. Thus, while the $\mathrm{AlOOH}$ phase present in sintered samples transform into $\mathrm{Al}_{2} \mathrm{O}_{3}$ after heat treatment, the temperature is too low to crystallize the amorphous phase and the resulting pellet must be a mixed amorphous-crystallized phase.

Fig. $4 \mathrm{a}$ and $\mathrm{b}$ display SEM micrographs of both the sintered boehmite pellet and the heated sintered $\gamma-\mathrm{Al}_{2} \mathrm{O}_{3}$ fractured samples. First, one can notice the very small grain size of both samples, with sizes below $100 \mathrm{~nm}$. As sintered sample $\left(380^{\circ} \mathrm{C}\right)$ consists in needle-like grains, with an average $10 \mathrm{~nm}$ width, $50 \mathrm{~nm}$ length. Applying the Scherrer formula on the XRD pattern of the sample sintered at $380^{\circ} \mathrm{C}$ gives an average crystallite size of $3.7 \mathrm{~nm}$ while the sample sintered at $400^{\circ} \mathrm{C}$ shows a crystallite size of $5.5 \mathrm{~nm}$. These crystallite sizes are in the same range as the one found for $\mathrm{ZrO}_{2}$ sintered in SPS at $350^{\circ} \mathrm{C}$ from $\mathrm{Zr}(\mathrm{OH})_{4}$ and determined by HR-SEM and Pair Distribution Function [8]. As mentioned earlier, as sintering temperature is increased, transition from $\mathrm{Al}(\mathrm{OH})_{3}$ to $\mathrm{AlOOH}$ progressively occurs and translucency increases concomitantly. Therefore, producing highly translucent, mechanically stable ceramics requires to find a balance between amorphous/crystalized phases.

Boehmite phase is a well-known precursor for the preparation of $\gamma-\mathrm{Al}_{2} \mathrm{O}_{3}$ with a phase transition expected at $500^{\circ} \mathrm{C}$ [15] and observed in DTA (see Fig. 2b). On Fig. 4 b, $\gamma-\mathrm{Al}_{2} \mathrm{O}_{3}$ microstructure still contains some elongated grains, which must come from the initial $\mathrm{AlOOH}$ phase, but most of them exhibit no specific shape. Their average size is preserved since it reaches $30 \mathrm{~nm}$. This phase transition consists in a topotactic transition with no lattice size modification $[25,28]$. Thus, it is possible to preserve the mechanical integrity of the sample without breaking it during the phase transition.

Using Aluminum hydroxide precursor allows the densification at temperature $\leq 400^{\circ} \mathrm{C}$ of boehmite phase $\gamma$-AlOOH. This densification occurs with a temperature dependent glass-ceramic composition evolution, both conferring the optical properties and ensuring the mechanical strength of the sample. Due to the topotactic phase transition existing between $\gamma$-AlOOH and $\gamma-\mathrm{Al}_{2} \mathrm{O}_{3}$ at temperature as low as $500^{\circ} \mathrm{C}$, it is possible to obtain dense samples of pure $\gamma-\mathrm{Al}_{2} \mathrm{O}_{3}$. The present work represents the first known example of a cold sintered sample with good optical translucency. Moreover, it is a great example of the possibility to preserve very low grain sizes along sintering with average grain sizes below $50 \mathrm{~nm}$ after sintering. In addition, the preparation of glass-ceramic materials opens new opportunities in tuning properties and offers a tool to control densification and sintering.

Cold Sintering Process allows for the first time the preparation of a dense sample of pure $\gamma-\mathrm{Al}_{2} \mathrm{O}_{3}$, a metastable phase that easily turns to $\alpha-\mathrm{Al}_{2} \mathrm{O}_{3}$ when heated up to temperatures of $1000-1100^{\circ} \mathrm{C}$ after intermediate phase transitions through $\delta\left(700-800^{\circ} \mathrm{C}\right)$ and $\theta$ $\left(900-1000^{\circ} \mathrm{C}\right)$ [15]. Due to the volume shrinkage induced by such phase transition, one must expect crack and pore formation. Obtaining dense $\alpha$-Al2O3 therefore implies to proceed through single step route to avoid these problems. However, the present results opens up opportunities in the preparation of transition alumina as sintered dense or porous samples. $\gamma-\mathrm{Al}_{2} \mathrm{O}_{3}$, which is often used for its high specific surface area, is a great candidate for the cold sintering of porous materials and shows the ability of Cold Sintering Process to apply in the field of catalytic and optical applications.

\section{Declaration of Competing Interest}

The authors declare that they have no known competing financial interests or personal relationships that could have appeared to influence the work reported in this paper.

\section{References}

[1] J. Guo, R. Floyd, S. Lowum, J.-P. Maria, T. Herisson De Beauvoir, J.H. Seo, C.A. Randall, Annu. Rev. Mater. Res. 49 (2019) 275-295.

[2] M.T. Sebastian, H. Wang, H. Jantunen, Curr. Opin. Solid State Mater. Sci. 20 (2016) 151-170.

[3] C. Vakifahmetoglu, L. Karacasulu, Curr. Opin. Solid State Mater. Sci. 24 (2020) 100807.

[4] M. Biesuz, G. Taveri, A.I. Duff, E. Olevsky, D. Zhu, C. Hu, S. Grasso, Adv. Appl. Ceram. 119 (2019) 75-89.

[5] F. Bouville, A.R. Studart, Nat. Commun. 8 (2017) 14655.

[6] S.H. Bang, T. Herisson de Beauvoir, C.A. Randall, J. Eur. Ceram. Soc. 39 (2019) 1230-1236.

[7] K. Tsuji, A. Ndayishimiye, S. Lowum, R. Floyd, K. Wang, M. Wetherington, J. Maria, C.A. Randall, J. Eur. Ceram. Soc. 40 (2019) 1280-1284.

[8] C. Elissalde, U.C. Chung, M. Josse, G. Goglio, M.R. Suchomel, J. Majimel, A. Weibel, F. Soubie, A. Flaureau, A. Fregeac, C. Estournès, Scr. Mater. 168 (2019) 134-138.

[9] T. Sada, K. Tsuji, A. Ndayishimiye, Z. Fan, Y. Fujioka, C.A. Randall, J. Eur. Ceram. Soc. (2020). 
[10] T. Herisson de Beauvoir, A. Sangregorio, I. Cornu, C. Elissalde, M. Josse, J. Mater. Chem. C 6 (9) (2018) 2229-2233.

[11] T. Herisson de Beauvoir, F. Molinari, U.C. Chung-Seu, D. Michau, D. Denux, M. Josse, J. Eur. Ceram. Soc. 38 (2018) 3867-3874.

[12] T. Herisson de Beauvoir, A. Sangregorio, I. Cornu, M. Josse, Dalt. Trans. 49 (2020) 7820-7828.

[13] H. Nakaya, M. Iwasaki, T. Herisson de Beauvoir, C.A. Randall, J. Eur. Ceram. Soc. 39 (2019) 396-401.

[14] T. Herisson de Beauvoir, A. Sangregorio, A. Bertrand, C. Payen, D. Michau, U.-C. Chung-Seu, M. Josse, Ceram. Int. 45 (2019) 9674-9678.

[15] I. Levin, D. Brandon, J. Am. Ceram. Soc. 81 (1998) 1995-2012.

[16] F. Balima, F. Bellin, D. Michau, O. Viraphong, A. Poulon-Quintin, U.C. Chung, A. Dourfaye, A. Largeteau, Mater. Des. 139 (2018) 541-548.

[17] C. Bousquet, C. Elissalde, C. Aymonier, M. Maglione, F. Cansell, J.M. Heintz, J. Eur. Ceram. Soc. 28 (2008) 223-228.

[18] F. Balima, A. Largeteau, Scr. Mater. 158 (2019) 20-23.
[19] Y. Zhang, J. Binner, J. Mater. Sci. Lett. 21 (2002) 803-805.

[20] M.A. González-Gómez, S. Belderbos, S. Yañez-Vilar, Y. Piñeiro, F. Cleeren, G. Bormans, C.M. Deroose, W. Gsell, U. Himmelreich, J. Rivas, Nanomaterials 9 (2019) 1626

[21] V. Saraswati, G.V.N. Rao, G.V. Rama Rao, J. Mater. Sci. 22 (1987) 2529-2534.

[22] M.C. Stegmann, D. Vivien, C. Mazieres, Spectrochim. Acta Part A Mol. Spectrosc 29 (1973) 1653-1663.

[23] A. Aminzadeh, Appl. Spectrosc. 51 (1997) 817-819.

[24] H.D. Ruan, R.L. Frost, J.T. Kloprogge, J. Raman Spectrosc. 32 (2001) 745-750.

[25] X. Krokidis, P. Raybaud, A.E. Gobichon, B. Rebours, P. Euzen, H. Toulhoat, J Phys. Chem. B 105 (2001) 5121-5130.

[26] Z.Y. Deng, T. Fukasawa, M. Ando, G.J. Zhang, T. Ohji, J. Am. Ceram. Soc. 84 (2001) 485-491

[27] R.J. Hill, Clays Clay Miner. 29 (1981) 435-445.

[28] J.-P. Jolivet, De La Solution à l'oxyde, EDP Science, 2015. 